\title{
Global events in sections of the Upper Devonian and Devonian/Carboniferous boundary interval (Western Bulgaria)
}

\section{Глобални събития в разрези на Горния Девон и на границата Девон/ Карбон (Западна България)}

\author{
Iliana Boncheva ${ }^{1}$, Valeri Sachanski ${ }^{1,2}$, Polina Andreeva ${ }^{1}$ \\ Илияна Бончева ${ }^{1}$, Валери Сачански ${ }^{1,2}$, Полина Андреева ${ }^{1}$ \\ ${ }^{1}$ Geological Institute, Bulgarian Academy of Sciences, Acad. G. Bonchev str., bl. 24, 1113 Sofia, Bulgaria; E-mails: \\ boncheva2005@yahoo.com; v_sachanski@geology.bas.bg; poly_a@abv.bg \\ ${ }^{2}$ University of Mining and Geology “St. Ivan Rilski”, 1 Prof. Boyan Kamenov str., Studentski Grad, 1700 Sofia, Bulgaria; \\ E-mail: v_sachanski@geology.bas.bg
}

\begin{abstract}
The Late Devonian (372-359 million AD) is a time of prolonged climate instability with catastrophic disturbances to global marine ecosystems at the Frasnian-Famennian (F/F) and Devonian-Carboniferous (D/C) boundaries. Global atmospheric $\mathrm{CO}_{2}$ content and climate change in the middle Paleozoic, especially in the Late Devonian, coincide with major events of extinction of organism groups. Anoxic intervals were documented within the Kellwasser event near the Frasnian/Famennian boundary (F/F), the Annulata event in Famennian and the Hangenberg event near the Famennian/Tournaisian boundary $(\mathrm{D} / \mathrm{C})$.
\end{abstract}

Keywords: Global events, Frasnian/Famennian, Devonian/Carboniferous, conodonts, Western Bulgaria.

За целите на това изследване са опробвани за конодонтна фауна 4 горнодевонски разреза с дълбоководна флишка седиментация: при селата Станьовци, Бераинци, Еловица и мах. Сулинци в Моравската единица. Къснодевонската турбидитна седиментация в Западна България продължава от Средния Девон до Ранния Карбон. Натрупването на девонски флишки седименти в Западна България бележи последния етап от развитието на палеозойския морски басейн, свързан с компресия и Вариската орогенеза. Флишката седиментация и преходът ѝ към дълбокобасейнова обстановка са датирани чрез конодонтна фауна като живет-раннокарбонска. При литоложкото изследване на флишкия разpez Yanev (1985) доказва тенденция към по-дълбоководни условия на басейна от средната част и до края на Девона. Изследваните разрези от Моравската единица при селата Еловица, Станьовци, мах. Сулинци и при с. Бераинци разкриват дълбоководна и непрекъсната седиментация в условията на флишки трог. Това е турбидитно редуване на аргилити, алевролити, пясъчници и на места конгломерати, с лидитни и карбонатни прослойки. Установени са конодонтните асоциации, индикиращи горнофаменската зона Palmatolepis expansa и последната фаменска зона Siphonodella praesulcata. Близо да границата Девон/Карбон има един кратък стратиграфски хиатус в конодонтната фауна, което може да се дължи на фациални причини. Тъй като намирането на конодонтна фауна е обвързано с наличието на карбонатни прослойки, каквито не се разкриват на границата с Карбона в тези разрези, засега не е установена първата турнейска зона - Siphonodella sulcata, но има данни за отгорележащата зона Siphonodella duplicata. Тези възрасти, доказани по конодонти в условията на флишка седиментация, дават възможност за дефиниране на последното глобално събитие в Девона (на границата с Карбона) - събитието Хангенберг (Hangenberg event). Датирането на девонските седименти в изследваните разрези е базирано на доминиращото присъствие на характерни конодонтни родове: Polygnathus, Ancyrodella, Palmatolepis и Siphonodella дават възможност за дефиниране на глобално събитие от първи порядък Kellwaser на границата Фран/ Фамен (фиг. 1А, Б).

Polygnathus е най-разпространеният род конодонти от девонските и карбонските разрези. Около 40 таксона са документирани в най-горните девонски и най-долните карбонски слоеве, но не всички имат важна стратиграфска стойност 


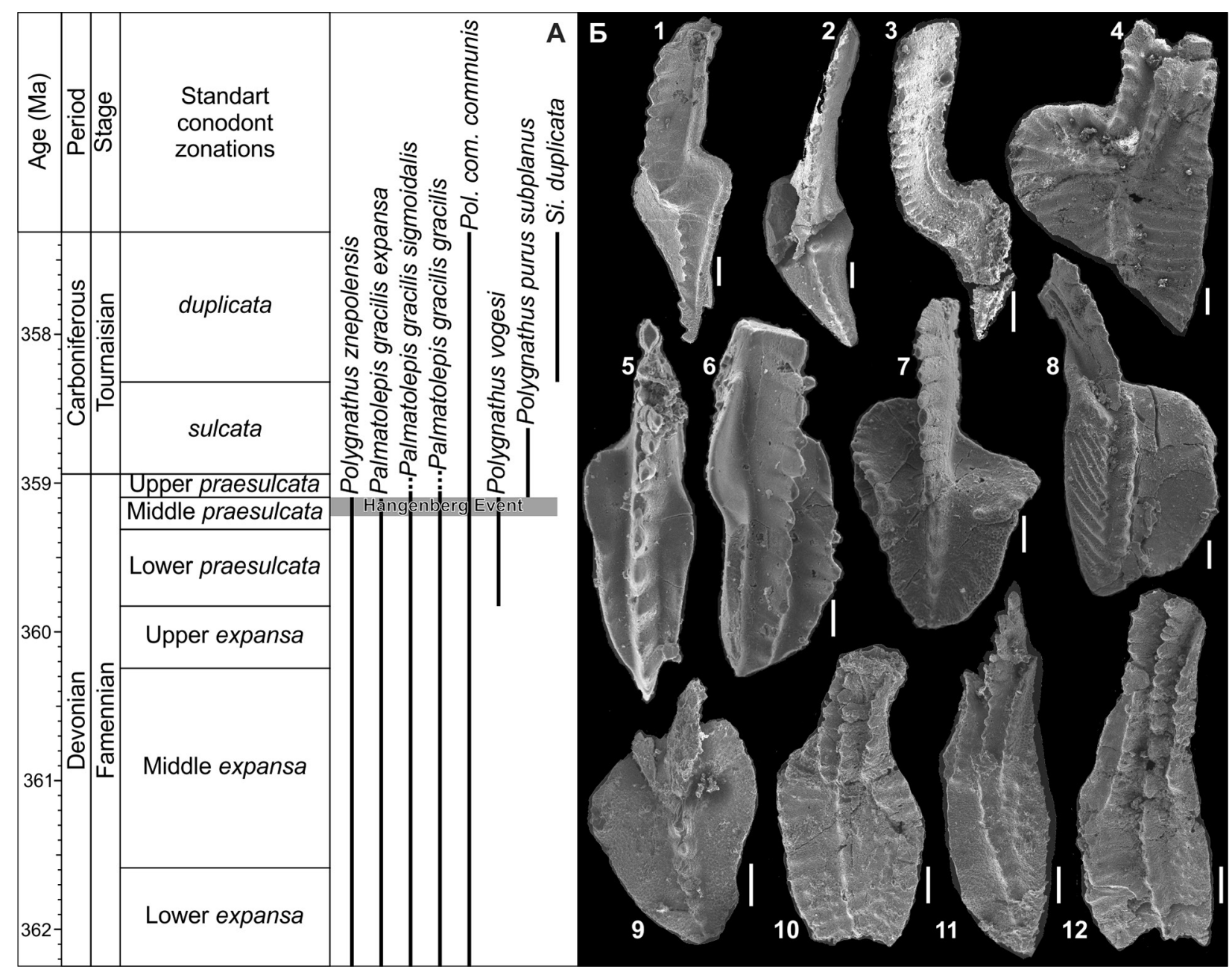

Фиг. 1. $A$ - зонална подялба и стратиграфско разпространение на характерна конодонтна асоциация на границата Девон-Карбон, индикираща глобалното събитие Хангенберг (Hangenberg global Event); Б - палеонтоложка таблица: 1 - Palmatolepis gracilis gracilis Branson \& Mehl; 2 - Palmatolepis gracilis expansa Sandberg \& Ziegler; 3 - Palmatolepis gracilis sigmoidalis Ziegler; 4 - Siphonodella lobata (Branson \& Mehl); 5 - Polygnathus communis communis Branson \& Mehl; 6 - Polygnathus vogesi Ziegler; 7 - Polygnathus znepolensis Spassov; 8 - Polygnathus purus subplanus Voges; 9 - Siphonodella duplicata sensu Hass. Бялата линийка отговаря на $100 \mu \mathrm{m}$.

или поради дълъг обхват, или поради ограничено регионално разпространение. Много видове са изчезнали в средната и горната Palmatolepis expansa зона. Характерният вид Polygnathus znepolensis Spassov е разпространен до края на средна Siphonodella praesulcata зона и достига до границата с Карбона до събитието Хангенберг (Hangenberg event), a Po. vogesi Ziegler се появява веднага след него. Тези видове са установени в разрезите при с. Станьовци и мах. Сулинци (фиг. 1Б).

Palmatolepis е доминиращият род в пелагичната обстановка през Късния Девон. Многобройни видове и подвидове са установени във франските и фаменските пластове, но разнообразието им намалява в края на Фамена и само няколко таксона са документирани в най- горните фаменски находища. Присъствието на видове на род Palmatolepis като Palmatolepis triangularis Sannemann, Palmatolepis cf. eureka Ziegler \& Sandberg, Palmatolepis subrecta Müller \& Joungquist, чиято пьрва поява е в основата на Фамена - зона Palmatolepis triangularis и наличието на Palmatolepis rhenana и Palmatolepis linguiformis индикират последната франска зона Palmatolepis linguiformis, където се доказва глобалното събитие Kellwasser на границата Фран/ Фамен в разрезите при с. Станьовци и мах. Сулинци. От особено значение е присъствието на видове от род Ancyrodella - Ancyrodella nodosa Ulrich \& Bassler, Ancyrodella ioides Ziegler, Ancyrodella gigas Youngquist, Ancyrodella soluta Sandberg, Ziegler, Bultynck, Ancyrodella rotundiloba (Briant), които принадлежат към горната част 
на Франа до последната зона - P. linguiformis. Наличието на много видове Ancyrodella и тяхното отсъствие в отгорележащата фаменска зона P. triangularis, както и появата на зоналния таксон Palmatolepis triangularis, маркират края на Франа и границата Фран/Фамен, а така също и за масовото изчезване на род Ancyrodella, заедно с много други организмови групи и биотопи. В най-високите стратиграфски нива на Фамена най-често срещаният вид на Palmatolepis е $P a$. gracilis, представен от няколко подвида. Pa. gracilis. expansa Sandberg \& Ziegler се появява в основата на долна Palmatolepis expansa зона до нивото на събитието Хангенберг (Hangenberg event). Най-характерните таксони от този запис са видовете Pa. gracilis gracilis Branson \& Mehl и Pa. gracilis sigmoidalis Ziegler, които са разпространени през по-голямата част от Фаменската епоха и изчезват в рамките на събитието Хангенберг или малко по-късно. Освен Pa. gracilis, само няколко таксона от Palmatolepis, принадлежащи към група „perlobata“, се срещат до горната част на зона praesulcata - последната фаменска конодонтна зона. Тези видове са установени в разрезите при с. Бераинци и с. Еловица.

В рамките на ранния ареал на разпространение на род Siphonodella са установени два таксона: Siphonodella praesulcata Sandberg и Siphonodella sulcata (Huddle). Тези видове са използвани в конодонтните зонални подялби за основни маркери при дефинирането на Турнейски етаж (Долен Карбон). Поради номенклатурни проблеми в диагностиката на Siphonodella sulcata и несигурната ѝ поява на границата Девон/Карбон, за индикирането ѝ е използван друг конодонтен таксон - Si. duplicata M1. Последният е добре познат, лесен за разпознаване и представен от относително много видове с широко географско разпространение. Според Sandberg et al. (1978, p. 105), Si. duplicata M1 еволюира от Si. sulcata (фиг. 1A).

Глобалното събитие Хангенберг (Hangenberg event), на границата Девон/Карбон (D/C), представлява масово изчезване на големи организмови групи от същия мащаб, както при така наречените фанерозойски събития от първи ред на „Голямата петорка“. Това събитие изиграва важна роля в еволюцията на много фаунистични групи като унищожава цялостни екосистеми, но засяга морската и сухоземната среда в малко пократък период от време. Кризисният интервал в най-горната част на Фаменския етаж започва с незначителен евстатичен спад на морското равнище, последван доста рязко от широко разпространено отлагане на черни шисти. Тази трансгресивна и аноксична фаза съвпадна с глобална карбонатна криза и смущения в глобалния въглероден цикъл, което се доказва от характерна положителна екскурзия на въглероден изотоп, вероятно като последица от еутрофикацията на външния шелф. При еутрофикацията настъпват няколко взаимосвързани неблагоприятни ефекта в екосистемата. Бурното развитие на водораслите на повърхността води до промяна на светлинните условия в по-дълбоките части на басейна, където по-дълбоководните алги загиват, образувайки токсични вещества. Причина за измиране както на водорасли, така и на риби и други водни обитатели, е и намаленото количество на кислород във водата. Това е основното ниво на изчезване за морската биота, особено за амоноидите, трилобитите, конодонтите, строматопороидите, коралите, някои акули и по-дълбоководните остракоди. Степента на изчезване е по-ниска за брахиоподи, остракоди, бриозои и бодлокожи.

Благодарности. Настоящото изследване е проведено във връзка с изпълнението на Национална научна програма (ННП) „Опазване на околната среда и намаляване на риска от неблагоприятни явления и природни бедствия“, одобрена с Решение на МС № 577/17.08.2018 г. и финансирана от МОН (Споразумение № Д01322/18.12.2019).

\section{Литература \\ References}

Sandberg, C.A., W. Ziegler, K. Leuteritz, S.M. Brill. 1978. Phylogeny, speciation, and zonation of Siphonodella (Conodonta, Upper Devonian and Lower Carboniferous). - Newsletters on Stratigraphy, 7, 2, 102-120.

Yanev, S. 1985. Devonian flysch in the Chernogorie (Southwest Bulgaria). - Paleontol., Stratigr. and Lithol., 21, 76-87. 